\title{
Raw Secondary Metabolites Application of Two Trichoderma harzianum Isolates towards Vascular Streak Dieback on Cocoa Seedlings
}

\author{
Loekas Soesanto ${ }^{1 *}$, Endang Mugiastuti ${ }^{1)}$, and Abdul Manan ${ }^{1)}$ \\ ${ }^{1}$ Faculty of Agriculture, Jenderal Soedirman University, Jl. dr. Suparno, Karangwangkal, Purwokerto 53123, Indonesia \\ ${ }^{*}$ Corresponding author: lukassus26@gmail.com \\ Received: 4 March 2019/ Accepted: 29 March 2019
}

\begin{abstract}
Abstrack
Vascular streak dieback is an important disease on cocoa that recently is still difficult to control. This research aimed to study the raw secondary metabolites application effectiveness of Trichoderma harzianum T10 and T213, or their combination to vascular streak dieback and its effect on growth and on phenolic compound of cocoa seedlings. Randomized block design was used with nine replicates. The treatments were control, secondary metabolites of T. harzianum T10 and T213, their combination and fungicide with active ingredient of phosphic acid. Variables observed were incubation period, disease intensity, plant height, number of leaves, wieght of fresh and dry plants, weight of fresh and dry roots, roots length, and phenolic compound. Result of the research showed that the raw secondary metabolites of $T$. harzianum $\mathrm{T} 10$ could suppress the disease intensity and delay the incubation period as 62.17 and $24.97 \%$, respectively. The raw secondary metabolites of $T$. harzianum T213 and T10 combination could increase plant height $36.21 \%$, number of leaves $19.07 \%$, fresh weight of plant $20.6 \%$, dry weight of plant $17.5 \%$, fresh weight roots $27 \%$, dry weight of root $34.36 \%$, and roots length $21.30 \%$. All raw secondary metabolites of $T$. harzianum were able to increase phenolic compounds (saponins, tannins, and glycosides) qualitatively of cocoa seedlings.
\end{abstract}

Keywords: Cacao seedlings, raw secondary metabolites, Trichoderma harzianum, vascular streak dieback

\section{INTRODUCTION}

Cocoa is one of plantation crops with high economic value. In 2010, Indonesia is the third largest exporter of cocoa beans world after Ivory Coast and Ghana (Bowers et al., 2001; Rubiyo \& Siswanto, 2012). According to data from the BPS (2015), in 2014, cocoa production has decreased by 11.53 thousand tons.

The decrease in production due to the constraint in improving the quality and production yield. Oncobasidium theobromae Talbot \& Keane cause xylem disease or
Vascular Streak Dieback (VSD) (Guest \& Keane, 2007; Samuels et al., 2012). Severe attacks can be deadly immature plants to 70\% (Keane, 1981). According Mulyatni et al. (2011), in Indonesia VSD reduce productivity by $40 \%$. If not promptly treated, the disease can be a major problem in the cultivation and production of cocoa.

Control is often done with fungicide. However, control with fungicides cannot be recommended, because the fungus is in the vessels (xylem), so it is difficult to obtain by fungicides (Yadeta $\&$ Thomma, 2013). In addition, excessive use of fungicides has 
negative impacts for the environment and human health (Eskenazi et al., 1999; Desneux et al., 2006; Geiger et al., 2011).

Accordingly, necessary to find other alternatives to control pathogen-causing VSD on cocoa. Secondary metabolites of biological agents, such as Trichoderma sp., were able to answer the challenges, which can reach the presence of the pathogen in plant tissue, and with diverse mechanisms (Ortuño et al., 2016).

A secondary metabolite is a chemical compound produced by a limited number of fungal species in a genus, an order, or even phylum. A profile of secondary metabolites consists of all the different compounds a fungus can produce on a given substratum and includes toxins, antibiotics and other outward-directed compounds (Frisvad et al., 2008). Raw secondary metabolites of T. harzianum are such as antibiotics, enzymes, hormones, and toxins (Reino et al., 2008; Keswan et al., 2014). Raw secondary metabolites of Trichoderma spp. may have a role in both plant growth regulation and activation of plant defence responses (Vinale et al., 2008a; Ortuño et al., 2016).

This study aimed to assess the effectiveness of raw secondary metabolites application of T. harzianum T10 and T213, or a combination thereof, to the vascular streak dieback and its impact on growth and the phenolic compounds in cocoa seedlings.

\section{MATERIALS AND METHODS}

\section{Pathogen Antagonist and Isolates}

Fungal pathogen isolate (Oncobasidium theobromae) was isolated from infected cacao stem (Prior, 1977), according to Baloiloi \& Akanda (2013). The purified culture was transferred to PDA slants and stored in the refrigerator for later use.
Preparation of T. harzianum T10 isolated from ginger (Soesanto et al., 2005) and T213 isolated from shallot (Santoso et al., 2007) rhizospheres was carried out on PDA, then, incubated for 7 days at room temperature. Both isolates of T. harzianum also be prepared in the corn broke medium, then incubated at room temperature about a week (Cavalcante et al., 2008; Panahian et al., 2012).

Raw secondary metabolites of two T. harzianum isolates was prepared in a liquid formula, which was composed of rice water as much as $8 \mathrm{~L}, 2 \mathrm{~L}$ coconut water and sugar $10 \mathrm{~g}$ per $\mathrm{L}$, sterilized and put into a sterile jerry cans (Soesanto et al., 2015). Furthermore, after cooling down, the medium is inoculated by $T$. harzianum derived from corn broke medium as many as $150 \mathrm{~g}$ with sterile water as much as $250 \mathrm{~mL}$, stirred until homogeneous then filtered and put into jerry cans and shaken using a shaker for 7 days at room temperature with a speed of $150 \mathrm{rpm}$ and then counted up the density of $10^{7}$ conidia per $\mathrm{mL}$ of solution, and filtered (Whatman no. 42).

\section{Inoculation Treatments}

Oncobasidium theobromae was inoculated on all seedlings leaves. The leaf was surface sterilized with $1 \%$ sodium hypochlorite for one minute and rinsed twice with distilled water. $O$. theobromae culture diameter of $5 \mathrm{~mm}$ cork borer was attached on the underside of the leaves, then covered the damp cotton as well as duct tape and wrapped in plastic (Baloiloi \& Akanda, 2013). Inoculation was also done on the roots of cacao seeds as much as 2 points with $5 \mathrm{~mm}$ cork borer of the culture, then, covered with soils.

Application of raw secondary metabolites of $T$. harzianum was performed using the root infusion of $50 \mathrm{~mL}$ per seedling. Application of raw secondary metabolites 
of $T$. harzianum do as much as 6 times at intervals of 6 days. Randomized block design with five treatments and six replications was used. The treatments tested included control, raw secondary metabolites of $T$. harzianum T10, T. harzianum T213, combination of T. harzianum $\mathrm{T} 213$ and $\mathrm{T} 10$, and fungicide with active ingredient of phosphite acid.

Patosistem component observed is the incubation period (dai) and the disease intensity (\%). The intensity of the disease is calculated using the formula according to Kranz (1988):

$$
\mathrm{I}=\frac{\sum(U x V)}{Z N} \times 100 \%
$$

where: $\quad \mathrm{S}(\mathrm{u} \times \mathrm{v})=$ Sum of the symptomatic plant and their corresponding score scale, $\mathrm{N}=$ Total number of sampled plant, and $\mathrm{Z}=$ Highest score scale.

According Nur'aini (2014), VSD categories based on the value of scoring as follows: $0=$ healthy; $1=<5 \%$ leaves infected; $2=$ $5-10 \%$ leaves infected, chlorosis/necrosis, no fallen leaves, lenticel swelling; $3=10-25 \%$ leaves infected, chlorosis/necrosis, lenticel swelling leaves falling down; $4=25-50 \%$ leaves infected, chlorosis/necrosis, lenticel swelling leaves falling down; $5=50-75 \%$ of infected leaves, chlorosis/necrosis, lenticel swelling leaves falling down; and $6 \Rightarrow 75 \%$ leaves infected, chlorosis/necrosis, lenticel swelling, leaves falling down, fruit body present, twigs are dead/dry.

Components of growth in terms of height, number of leaves, plant fresh weight, dry weight of plants, fresh root weight, dry root weight and root length. Analysis of phenolic compounds qualitatively carried out at the end research. Test of saponins and tannins conducted by Astuti (2011), and glycosides test conducted by Chairul (2003).

Data were analyzed by analysis of variance at the level of 5\% error. If significantly different between treatments, was tested fur- ther using Duncan Multiple Range Test with a level of $5 \%$.

\section{RESULTS AND DISCUSSION}

\section{Incubation and Disease Intensity}

The application of raw secondary metabolites of T. harzianum T10 significantly affected the incubation period compared to control and fungicide (Table 1). The raw secondary metabolites of T. harzianum T10 did not differ with the other treatments. The raw secondary metabolites of $T$. harzianum $\mathrm{T} 10$ could prolonge the incubation period as long as 15 and 18.89 dai or as $24.98 \%$ and $31.45 \%$ compared to control and fungicide, respectively. Although the other aplication did not differ significantly with $T$. harzianum $\mathrm{T} 10$, the raw secondary metabolites of $T$. harzianum T213 and the combination could lengthen the incubation period respectively as 13.05 dai or $22.46 \%$ and 6.72 dai or $12.98 \%$ compared to control and as 16.94 dai or $29.15 \%$ and 10.61 dai or $20.49 \%$, respectively, compared to fungicide.

The raw secondary metabolites of T. harzianum $\mathrm{T} 10$ significantly different with control and fungicides (Table 1). Control tended to show the higher disease intensity compared to the raw secondary metabolites of $T$. harzianum. The same thing happened in the fungicide that the fungicide has not been able to lower the disease intensity. In contrast, the raw secondary metabolites of T. harzianum $\mathrm{T} 10$ had a smaller intensity of the disease or was able to suppress the disease intensity by $62.17 \%$ and $69.76 \%$ when compared to the control and fungicide, respectively. Application of T. harzianum T213 raw secondary metabolites was not significantly different to controls, but significantly different with fungicide. The raw secondary metabolites of the combined T. harzianum isolates were not significantly 
different either to the control or fungicide. Although it was not significantly different statistically (Table 1), the raw secondary metabolites of T. harzianum T213 and the combined isolates generally suppressed the development of $O$. theobromae as 44.68 and $22.44 \%$, respectively, when compared to control.

Table 1. The effect of treatments on pathosystem component

\begin{tabular}{lcc}
\hline Treatment & $\begin{array}{c}\text { Incubation } \\
\text { period (dai) }\end{array}$ & $\begin{array}{c}\text { Disease } \\
\text { intensity }(\%)\end{array}$ \\
\hline Control & $45.06 \mathrm{bc}$ & $15.15 \mathrm{~b}$ \\
T. harzianum T10 & $60.06 \mathrm{a}$ & $5.73 \mathrm{c}$ \\
T. harzianum T213 & $58.11 \mathrm{ab}$ & $8.38 \mathrm{bc}$ \\
T. harzianum T10 + T213 & $51.78 \mathrm{abc}$ & $11.75 \mathrm{abc}$ \\
Fungicide (phosphite acid) & $41.17 \mathrm{c}$ & $18.95 \mathrm{a}$ \\
\hline Note: - dai = days after inoculation. \\
\multicolumn{2}{c}{ - Figures in the same column followed by the same } \\
\multicolumn{2}{l}{ letter are not significantly different. }
\end{tabular}

\section{Plant Growth}

The application of raw secondary metabolites of $T$. harzianum was significantly different from the control treatment and fungicide (Table 2). The raw secondary metabolites of T. harzianum T10, T213, and the combination could promote the cacao seedling height respectively as high as 3.35, 2.29, and $2.89 \mathrm{~cm}$ or as $39.69,31.03$, and $36.22 \%$ compared to control and as 3.09, 2.03, and $2.63 \mathrm{~cm}$ or as $36.61,27.51$, and $32.96 \%$ compared to fungicide, respectively.

Application of T. harzianum raw secondary metabolites was significantly different to the control and fungicide. The raw secondary metabolites of T. harzianum T10, T213, and their combination significantly affected in increasing the number of leaves by 20.67 , 18.50 , and $19.08 \%$, respectively, when compared to control and as $30.31,28.40$, and $28.91 \%$, respectively, when compared to fungicide.

The weight of fresh cacao seedlings showed no significant difference between treatments (Table 2). The raw secondary metabolites of $T$. harzianum combined isolates were significantly different to control and fungicide. Control and fungicide had lower fresh weight of the plant compared with the combination of $T$. harzianum isolates. All applications of T. harzianum raw secondary metabolites were not significantly different but the use of raw secondary metabolites of $T$. harzianum combined isolates showed an increase of $20.6 \%$ compared to all treatments.

The treatments were not significantly different on weight of dry cacao seedlings. Although no difference statistically (Table 2), it was presumably that the raw secondary metabolites of $T$. harzianum generally gave rise to dry weight of the plant each at 8.8, 14.7 , and $17.5 \%$ when compared to controls.

The raw secondary metabolites of T. harzianum alone or in combination affected significantly in increasing fresh and dry root weight compared with the control and fungicide. Fungicide and controls show fresh and dry root weight is lower compared to the secondary metabolites of $T$. harzianum. The raw secondary metabolites of $T$. harzianum both T10 and T213 isolates and their combination was able to increase the weight of fresh root as $25.7,18.2$, and $34.36 \%$, respectively, and increase the weight of the dried root as $34.76,24.94$, and $34.36 \%$, respectively.

Table 2. The effect of the treatments on growth

\begin{tabular}{lccccccc}
\hline Treatment & TT $(\mathrm{cm})$ & JD & BTS $(\mathrm{g})$ & BTK $(\mathrm{g})$ & BAS $(\mathrm{g})$ & BAK $(\mathrm{g})$ & PA $(\mathrm{cm})$ \\
\hline Control & $5.09 \mathrm{~b}$ & $6.83 \mathrm{~b}$ & $24.38 \mathrm{~b}$ & 5.77 & $6.44 \mathrm{~b}$ & $3.19 \mathrm{~b}$ & $24.89 \mathrm{~b}$ \\
T. harzianum $\mathrm{T} 10$ & $8.44 \mathrm{a}$ & $8.61 \mathrm{a}$ & $25.72 \mathrm{ab}$ & 6.33 & $8.67 \mathrm{a}$ & $4.89 \mathrm{a}$ & $30.97 \mathrm{a}$ \\
T. harzianum $\mathrm{T} 213$ & $7.38 \mathrm{a}$ & $8.38 \mathrm{a}$ & $26.16 \mathrm{ab}$ & 6.77 & $7.88 \mathrm{ab}$ & $4.25 \mathrm{ab}$ & $30.63 \mathrm{a}$ \\
T. harzianum $\mathrm{T} 10+\mathrm{T} 213$ & $7.98 \mathrm{a}$ & $8.44 \mathrm{a}$ & $30.72 \mathrm{a}$ & 7.00 & $8.83 \mathrm{a}$ & $4.86 \mathrm{a}$ & $31.63 \mathrm{a}$ \\
Fungicide (phosphite acid) & $5.35 \mathrm{~b}$ & $6.00 \mathrm{~b}$ & $20.55 \mathrm{~b}$ & 5.61 & $6.56 \mathrm{~b}$ & $3.56 \mathrm{~b}$ & $26.65 \mathrm{ab}$ \\
\hline Note: & Figures followed by the same letter in the same column showed no significant difference in DMRT 5\%. TT = plant \\
\multicolumn{7}{l}{ height, JD = number of leaves, BTS = Weight of fresh plants, BTK = Weight of dried plants, BAS = Weight of } \\
fresh roots, BAK = Weight of dry roots, and PA = length of roots.
\end{tabular}


The raw secondary metabolites of T. harzianum T10, T213, and the combined isolates were significantly different when compared to control (Table 2). The raw secondary metabolites of $T$. harzianum $\mathrm{T} 10$, $\mathrm{T} 213$, and the combined isolates were able to increase the length of roots as $19.63,18.73$, and $21.30 \%$, respectively, when compared to control.

\section{Phenolic Compounds}

Cacao seedlings contained phenolic compounds (Table 3 ). The content of saponins, tannins, and glycosides in raw secondary metabolite application of $T$. harzianum was more compared to the control and fungicide. The raw secondary metabolites $T$. harzianum T10, T213, and the combined isolates could increase the phenolic compounds content of cacao seedlings qualitatively.

Table 3. The cocoa seedlings phenolic compound qualitatively

\begin{tabular}{lccc}
\hline Treatment & Saponin & Tannins & Glycosides \\
\hline Control & + & + & + \\
T. harzianum $\mathrm{T} 10$ & ++ & ++ & ++ \\
T. harzianum $\mathrm{T} 213$ & ++ & ++ & +++ \\
T. harzianum $\mathrm{T} 10+$ & ++ & ++ & ++ \\
T213 & & & + \\
Fungicide & + & + & + \\
(phosphite acid) & & & + \\
\hline Note: $\quad-=$ no phenol content. $+=$ a little, $++=$ sufficient, \\
\multicolumn{2}{l}{ and $+++=$ lots. }
\end{tabular}

The different data of incubation period is presumably because the plants in the control was not applied secondary metabolites of T. harzianum, so it does not have a mechanism of suppression against $O$. theobromae infection. This is in accordance with the opinion of Soesanto \& Rahayuniati (2009), that the plants are not applied biological agents do not have a mechanism of suppression against pathogen infection. The same thing happened to fungicide which shows the faster incubation period compared to the treatment of $T$. harzianum raw secondary metabolites applications. The fungicide active ingredient of phosphite acid have not been able to suppress the growth of pathogenic O. theobromae.

The delay was allegedly due to the application of $T$. harzianum raw secondary metabolites that was able to induce resistance against $O$. theobromae in cocoa seedlings. Inducement is evident with the increase of phenolic compounds in cocoa seedlings were treated with raw secondary metabolites of T. harzianum (Table 3). This is supported by Soesanto et al. (2015), that the secondary metabolite is able to induce plant resistance, so that the plant can withstand and avoid the attack of pathogen. Plants that are applied with the raw secondary metabolites of T. harzianum suspected to have the suppression infection mechanism against $O$. theobromae. This is in accordance with the opinion of Suganda (2000), that presses against pathogen infection can occur with performed award antagonistic microbes, chemicals, compost, and plant extracts instead of the host.

High disease intensity was found in the control and fungicide because of no raw secondary metabolites application of $T$. harzianum so that in the control and fungicide, young leaves faster attacked because young leaves are more susceptible to pathogens (Guest \& Keane, 2007). O. theobromae is an airborne pathogens and faster infect young leaves. This statement is supported the fact that $O$. theobromae infect plants through young leaves, on the second or third flush behind the tip (Guest \& Keane, 2007; Baloiloi \& Akanda, 2013).

In contrast, the raw secondary metabolites applications of $T$. harzianum $\mathrm{T} 10$ is able to suppress the disease intensity by $62.17 \%$ when compared to the control and fungicide. It is because the raw secondary metabolites of T. harzianum able to increase the phenolic compounds in plants (Table 3), which serves as a plant defense against 
pathogen infection. According Schulz et al. (2002), the higher the content of phenolic compounds in plants, the higher the plant resistance to pathogen infection so that the disease intensity is low.

The secondary metabolites of $T$. harzianum suspected of having the suppression infection mechanism against $O$. theobromae. The pathogen can not spread to the entire network of plants or the location of the attack is limited, so that the disease intensity is not high. This statement is supported by Guest \& Keane (2007).

According to Agrios (2005), a pathogen that generally colonize dead tissue will be inhibited by biological agents, so as to reduce the progression of disease in the plant tissue. The disease intensity in the raw secondary metabolites of T. harzianum T213 and their combined treatment in harmony with the incubation period. In addition, the raw secondary metabolites contains more phenolic compounds than in controls (Table 3). According Schulz et al. (2002), phenolic compound serves as a plant defense against pathogen infection. Further explained Agrios (2005), that an increase in phenolic compounds in plants due to the addition of fungal metabolites antagonist is absorbed by plants and translocated systemically to all parts of the plant, causing the substance responsible in induced resistance, among which is a phenol compound.

The application of $T$. harzianum raw secondary metabolites affected significantly seedlings growth components (Table 2). The low height of plants is found in the control and fungicide allegedly because the intensity of the attack pathogens and lack of $O$. theobromae attack control by secondary metabolites of biological agents so the plants become stunted growth. According Guest \& Keane (2007), the attack of pathogens that cause chlorosis on the leaves can disrupt the process of photosynthesis so the growth becomes stunted.
The increase in plant height alleged activity of raw secondary metabolites of $T$. harzianum. Besides being able to suppress the pathogen attack, secondary metabolites can trigger the growth of plants. This is according to Kliebenstein et al. (2005), that the secondary metabolite of biological agents was capable of double plays both in reducing the pest attack plantations as well as the growth and production of the host plant.

The low amount of leaves in the control and fungicide due to the control and fungicide are not applied the secondary metabolites, thus leading to high intensity resulting disease infected leaves become deciduous. This is consistent with Guest \& Keane (2007) that the disease can cause twig toothless VSD for leaf experiencing hair loss. Increasing the number of leaves presumably because the secondary metabolites of $T$. harzianum can affect plant growth. This statement is supported by Vinale et al. (2008b).

Control and fungicides have a fresh weight of plants is low compared with the treatment of $T$. harzianum isolates combination. This is presumably because the high pathogenic attack resulted in the growth of the plants become stunted. This is in accordance with the intensity of the disease in fungicide and control for the percentage intensity is higher than other treatments. In addition. the process of photosynthesis in symptom leaves will be disrupted because of damage to the chloroplast. The result would not be optimum photosynthesis process so that the plant growth will be impaired. According to McMahon \& Purwantara (2016), that pathogen infected young leaves of cacao seedlings and mature trees, symptoms of leaf chlorosis, leaf fall, and branch dieback or seedling mortality leading to inhibition of plant growth.

Increased weight of the fresh plant legedly because the secondary metabolites is used to have a mechanism of plant growth 
promoting fungi so that the secondary metabolites of $T$. harzianum were able to stimulate plant growth. This is consistent with an increase in the number of leaves and plant height at application treatment of secondary metabolites of $T$. harzianum combined isolates. This statement is supported by Vinale et al. (2008a) that one of the biological agents secondary metabolites functions was to stimulate and generate growth regulators.

Application of T. harzianum raw secondary metabolites was able to increase saponins, tannins, and glycosides in plants that can induce plant resistance (Table 3), so that the development of the pathogens in the plants become inhibited. The symptoms are not widespread and the process of photosynthesis in the leaves still occur. This causes good plant growth so it affected plant fresh weight (Anggraeni \& Wibowo, 2007). Increased weight of the fresh plant in line with the increase in the value of the plant dry weight, root wet weight, dry root weight, and root length that have better value compared to growth component of other treatments.

Increased weight of the dried plants in secondary metabolites applications of $T$. harzianum in line with the increased weight of the fresh plant. The increased weight of the dried plant suspected because of the application of $T$. harzianum secondary metabolites. The provision of secondary metabolites of $T$. harzianum allegedly able to suppress the growth of pathogenic $O$. theobromae so the optimum cocoa seedlings can grow and be able to increase plant growth. This statement is supported by the results of research Aziz et al. (2015) that the application of secondary metabolites of $T$. harzianum T213, T10, and their combination can suppress the intensity of bacterial wilt by $51.72 \%$ and to increase the potato crop dry weight by $34.9 \%$.

The low weight of fresh and dry roots on the control and fungicide allegedly was not applied the secondary metabolites of
T. harzianum so that the intensity of the disease is high which results in the process of photosynthesis becomes blocked and the impact on root growth to be disturbed. According Wasis et al. (2011), root growth is dependent on the active area of leaf photosynthesis. because the roots will receive energy only when there is excess energy that is not used for the growth of the plant canopy.

Fungicides used allegedly does not contain growth hormones. According Mkdgroup (2011), fungicide active ingredient folirfos with phosphorous acid can only control the development of pathogens in plants.

The increase in root weight allegedly due to the application of secondary metabolites of $T$. harzianum can enhance root growth. Secondary metabolites of T. harzianum contains growth hormones that can stimulate the growth of plant roots. This statement is supported by Druzhinina et al. (2011) that Trichoderma sp. can stimulate the formation of lateral roots, for issuing a kind of hormone auxin active substance that stimulates lateral root formation.

This is presumably because the control was not applied to the secondary metabolites of Trichoderma sp. so that the roots of cocoa seedlings colonized by pathogens $O$. theobromae. This statement is supported by Harlina (2009) that the inhibition of root growth occurs in the area because of constraints on protein synthesis in the root elongation. Barriers protein synthesis is caused by the limited components of macromolecules as well as the existence of barriers synthesis and activity of enzymes in the process of protein synthesis. The inhibitory effect was caused by pathogenic fungi.

Increased root elongation allegedly was because the raw secondary metabolites capability of $T$. harzianum trigger the growth of plant roots. According to Moeinzadeh et al. (2010), microbial activity antagonist as 
PGPF because it can produce growth hormone to stimulate the extension of the roots. This statement is supported by Nurahmi et al. (2012) that the application of T. harzianum can affect root extension cocoa seeds. More Cleland (1972) explains that the species T. harzianum can produce indolasetat acid (IAA) and other materials related to auxin.

The increase in phenolic compounds in plant tissue is suspected because the application of T. harzianum raw secondary metabolites on cocoa seedlings were able to increase the content of saponins, tannins and glycosides in the plant. This statement is reinforced by Agrios (2005) that the increase in phenol content in plants for fungal antagonist used supernatant is absorbed by plants and translocated systemically to all parts of the plant, causing the substance responsible for the resilience of the affected including phenolic compounds.

This proves that the raw secondary metabolite of $T$. harzianum can enhance phenolic compounds in cacao seedlings so the impact on plant resistance. The plants become susceptible to pathogens so the value of the intensity of the disease in the raw secondary metabolites of $T$. harzianum lower and a long incubation period compared with the control and fungicide. According to Wachjadi et al. (2013), phenolic compounds responsible for plant resistance to pathogen attack. The high intensity of the disease in fungicides and control due to low saponins, tannins and glycosides in plant. Phenolic compounds in plants plays an important role on the mechanisms of plant resistance to pathogen attack. If the content of phenolic compounds is low then the plant has a low resistance of infection pathogens. This is in accordance with Wachjadi et al. (2013), a plant that has a low content of phenolic compounds. The plant resistance to infectious diseases will decline. so that the intensity of the disease is high.

\section{CONCLUSION}

Treatment using raw secondary metabolites of T. harzianum T10 could suppress disease intensity by $62.17 \%$. and were able to delay the incubation period amounted to $24.97 \%$. The raw secondary metabolites of the combined T. harzianum T213 and T10 could improve plant height, number of leaves, plant fresh weight, plant dry weight, root fresh weight, root dry weight, and root length in the range of $17.5-36.2 \%$. Treatment of raw secondary metabolites of $T$. harzianum was capable of increasing the phenolic compounds (saponins, tannins, and glycosides) content in the plants tissues that play a role in building the plant resistance to VSD.

\section{ACKNOWLEDGEMENT}

This research did not receive any specific grant from funding agencies in the public, commercial, or not-for-profit sectors. We thank UPTD Plantation Institute, Central Sulawesi, for providing the cocoa VSD symptoms. Thanks go to Lusi Yulandari for technical assistance.

\section{REFERENCES}

Agrios, G.N. (2005). Plant Pathology. $5^{\text {th }}$ ed. Elsevier Academic Press. California.

Anggraeni, I. \& A. Wibowo (2007). Pengaruh pola tumpangsari agroforestri terhadap insidensi penyakit dan produktivitas tanaman. Pusat Penelitian dan Pengembangan Hutan Tanaman, 2, 59-70.

Astuti, E.P. (2011). Efektivitas minyak jarak sebagai larvisida, anti-peneluran, dan ovisida terhadap larva nyamuk Aides albopictus. Buletin Littro, 22, 44-53.

Aziz, B.I. (2015). Aplikasi dua isolat Trichoderma harzianum untuk mengendalikan layu bakteri pada kentang. Skripsi. Fakultas Pertanian. Universitas Jenderal Soedirman. Purwokerto. 67 hal. 
Baloiloi, D.S. \& S. Akanda (2013). Screening of cocoa seedlings for resistence to vascular streak dieback through leaf disc inoculation. Niugini Agrisaiens, 5, 19-27.

Bowers, J.H.; B.A. Bailey; P.K. Hebbar; S. Sanogo \& R.D. Lumsden (2001). The impact of plant diseases on world chocolate production. Plant Health Progress.

BPS (2015). Produksi Tanaman Perkebunan Menurut Provinsi dan Jenis Tanaman, Indonesia (000 Ton) 2012-2014. Badan Pusat Statistik, Indonesia.

Cavalcante R.S.; H.L.S. Lima; G.A.S. Pinto; C.A.T. Gava \& S. Rodrigues (2008). Effect of moisture on Trichoderma conidia production on corn and wheat bran by solid state fermentation. Food Bioprocess Technology, 1, 100-104.

Chairul (2003). Identifikasi cepat bahan bioaktif tanaman di lapang. Berita Biologi, 6, 621-628.

Cleland, R. (1972). The dosage-response curve for auxin-induced cellelongation: are-evaluation. Planta, 104, 1-9.

Desneux, N.; A. Decourtye \& J.-M. Delpuech (2006). The sublethal effects of pesticides on beneficial arthropods. Annual Review of Entomology, 52, 81-106.

Druzhinina, I.S.; V. Seidl-Seiboth; A. HerreraEstrella; B.A. Horwitz; C.M. Kenerley; E. Monte; P.K. Mukherjee; S. Zeilinger; I.V. Grigoriev \& C.P. Kubicek (2011). Trichoderma: the genomics of opportunistic success. Nature Reviews Microbiology, 9, 749-759.

Eskenazi, B.; A. Bradman \& R. Castorina (1999). Exposures of children to organophosphate pesticides and their potential adverse health effects. Environ Health Perspect, 107(Suppl 3), 409-419.

Frisvad, J.C.; B. Andersen \& Thrane U. (2008). The use of secondary metabolite profiling in chemotaxonomy of filamentous fungi. Mycological Research, 112, 231-240.

Geiger, F.; J. Bengtsson; F. Berendse; W.W. Weisser; M. Emmerson; M.B. Morales; P. Ceryngier;
J. Liira; T. Tscharntke; C. Winqvist; S. Eggers; R. Bommarco; T. Pärt; V. Bretagnolle; M. Plantegenest; L.W. Clement; C. Dennis; C. Palmer; J.J. Oñate; I. Guerrero; V. Hawro; T. Aavik; C. Thies; A. Flohre; S. Hänke; C. Fischer; P.W. Goedhart \& P. Inchausti (2011). Persistent negative effects of pesticides on biodiversity and biological control potential on European farmland. Basic and Applied Ecology, 12, 386-387.

Guest, D. \& P. Keane (2007). Vascular-Streak Dieback: A new encounter disease of Cacao in Papua New Guinea and Southeast Asia caused by the obligate Basidiomycete Oncobasidium theobromae. Phytopathology, 97, 1654-7.

Harlina, L. (2009). Potensi Trichoderma harzianum sebagai biofungisida pada tomat. Biosaintifika, 1, 62-69.

Keane, P.J. (1981). Epidemiology of vascularstreak dieback of cocoa. Annals of Applied Biology, 88, 227-141.

Keswan, C.; S. Mishra; B.K. Sarma; S.P. Singh; H.B. Singh (2014). Unraveling the efficient applications of secondary metabolites of various Trichoderma spp. Applied Microbiology and Biotechnology, 98, 533-544.

Kliebenstein, D.J.; H.C. Rowe; K.J. Denby (2005). Secondary metabolites influence Arabidopsis/Botrytis interactions: variation in host production and pathogen sensitivity. The Plant Journal, 44, $25-36$.

Kranz J. (1988). Measuring plant disease. p. 35-50. In: Experimental Techniques in Plant Disease Epidemiology (J. Kranz \& J. Rotem, Eds.). Springer, Berlin.

McMahon, P. \& A. Purwantara (2016). Vascular streak dieback (Ceratobasidium theobromae): History and biology. In: B. Bailey \& Meinhardt L. (Eds.), Cacao Diseases. Springer, Cham.

Mkdgroup (2011). Folirfos 400 SL. http://mkdgroup. $\mathrm{com} / \mathrm{mkd}$ /fungisida.produk-folirfos400-sl-88.html. Diakses 9 Januari 2016. 
Moeinzadeh, A.; F. Sharif-Zadeh; M. Ahmadzadeh; \& F.H. Tajabadi (2010). Biopriming of sunflower (Helianthus annuus L.) seed with Pseudomonas fluorescens for improvement of seed invigoration and seedling growth. Australian Journal of Crop Science, 4, 564-570.

Mulyatni, A.S.; A. Priyatmojo \& A. Purwantara (2011). Sequence of internal transcribed Spacer (ITS) DNA ribosomal Oncobasidium theobromae dan membandingkan fungi sekerabat. Menara Perkebunan, 79, 1-5.

Nur'aini, F. (2014). Pengendalian vascular streak dieback pada tanaman kakao menggunakan fungisida flutriafol. Pelita Perkebunan, 30, 229-239.

Nurahmi, E.; Susanna \& R. Sriwati (2012). Pengaruh Trichoderma terhadap perkecambahan dan pertumbuhan biji kakao, tomat, dan kedelai. Jurnal Florateknologi, 7, 57-65.

Ortuño, N.; J.A. Castillo; C. Miranda \& M. Claros (2016). The use of secondary metabolites extracted from Trichoderma for plant growth promotion in the Andean highlands. Renewable Agriculture and Food Systems, 1-10.

Panahian, Gh.; K. Rahnama \& M. Jafari (2012). Mass production of Trichoderma spp and application. International Research Journal of Applied and Basic Sciences, 3, 292-298.

Prior, S. (1977). Growth of Oncobasidium theobromae Talbot \& Keane in dual culture with callus tissue of Theobroma cacao L. Journal of General Microbiology, 99, 219-222.

Reino, J.L.; R.F. Guerrero; R. Hernández-Galán \& I.G. Collado (2008). Secondary metabolites from species of the biocontrol agent Trichoderma. Phytochemistry Reviews, 7, 89-123.

Rubiyo \& Siswanto (2012). Peningkatan produksi dan perkembangan kakao (Theobroma cacao L.) di Indonesia. Buletin Ristri, 3, 33-48.

Samuels, G.J.; A. Ismaiel; A. Rosmana; M. Junaid; D. Guest; P. McMahon; P. Keane;
A. Purwantara; S. Lambert; M. RodriguezCarres \& M.A. Cubeta (2012). Vascular streak dieback of cacao in Southeast Asia and Melanesia: in planta detection of the pathogen and a new taxonomy. Fungal Biology, 116, 11-23.

Schulz, B.; C. Boyle; S. Draeger; A.-K. Römmert \& K. Krohn (2002). Endophytic fungi: a source of novel biologically active secondary metabolites. Mycological Research, 106, 996-1004.

Santoso, S.E.; L. Soesanto \& T.A.D. Haryanto (2007). Pengendalian hayati penyakit moler pada bawang merah dengan Trichoderma harzianum, Trichoderma coningii, dan Pseudomonas fluorescens P60. Jurnal Hama dan Penyakit Tumbuhan Tropika, 7, 53-61.

Soesanto, L.; Soedharmono; N. Prihatiningsih; A. Manan; E. Iriani \& J. Pramono (2005). Potensi agensia hayati dan nabati dalam mengendalikan busuk rimpang jahe. Jurnal Hama dan Penyakit Tumbuhan Tropika, 5, 50-57.

Soesanto, L. \& R.F. Rahayuniati (2009). Pengimbasan ketahanan bibit pisang Ambon kuning terhadap layu fusarium dengan beberapa jamur antagonis. Jurnal Hama dan Penyakit Tumbuhan Tropika, 9, 130-140.

Soesanto, L.; B. Prakoso; E. Mugiastuti \& R.F. Rahayuniati (2015). Kajian empat senyawa organic cair terhadap pertumbuhan empat isolat Trichoderma sp. Kongres XXIII dan Seminar Ilmiah Perhimpunan Fitopatologi Indonesia, Balai Uji Teknik Terapan dan Metode Karantina Pertanian, Bekasi, 11-13 November 2015.

Suganda, T. (2000). Induksi ketahanan sistemik cabai merah terhadap penyakit antraknosa dengan aplikasi induser biotik dan abiotik. Jurnal Agrikultura, 11, 67-75.

Vinale, F.; K. Sivasithamparam; E.L. Ghisalberti; R. Marra; M.J. Barbetti; H. Li; S.L. Woo \& M. Lorito (2008a). A novel role for Trichoderma secondary metabolites in the interactions with plants. Physiological and Molecular Plant Pathology, 72 (1-3), 80-86. 
Vinale, F.; K. Sivasithamparam; E.L. Ghisalberti; R. Marra; S.L. Woo \& M. Lorito (2008b). Trichoderma-plant-pathogen interactions. Soil Biology \& Biochemistry, 40, $1-10$.

Wachjadi, M.; L. Soesanto; A. Manan \& E. Mugiastuti (2013). Pengujian kemampuan mikroba antagonis untuk mengendalikan penyakit hawar daun dan layu bakteri pada tanaman kentang di daerah endemis. Agrin, 17, 94-102.
Wasis, B.; Y. Setiadi \& H.B. Tarigan (2011). Pertumbuhan bibit Jabon (Anthocephalus cadamba Roxb. Miq.) pada media tailings PT. ANTAM unit bisnis pongkor dengan penambahan top soil dan kompos. Jurnal Silcikultur Tropika, 2, 136-142.

Yadeta, K.A. \& B.P.H.J. Thomma (2013). The xylem as battleground for plant hosts and vascular wilt pathogens. Frontier of Plant Science, 4, 97.

$$
* * 0 * *
$$

